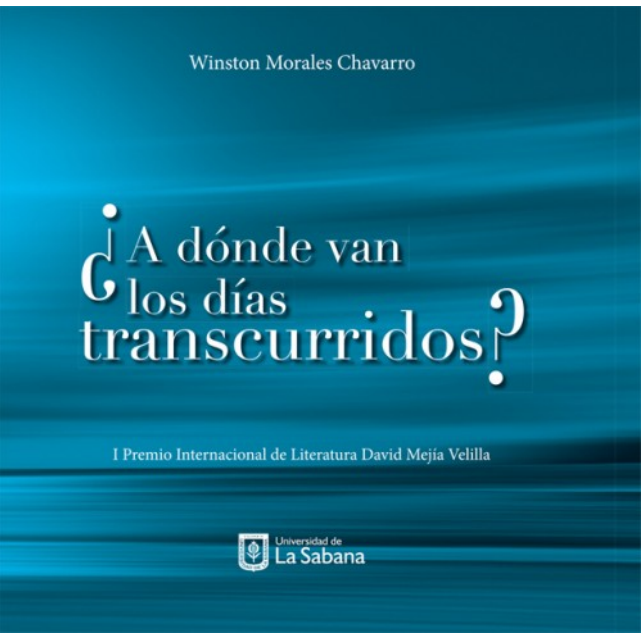

\title{
¿A DÓNDE VAN LOS DÍAS TRANSCURRIDOS?
}

Por: Winston Morales Chavarro

Formato: Digital

ISBN: 978-958-12-0386-4

Facultad: Filosofía y Ciencias Humanas, Open Access

Idioma: Español

Precio en dólares: USD $\$ 0,00$

Palabras clave: Literatura colombiana - Siglo XX, Poesía colombianos - Siglo

XX, Realidad en la literatura

\section{$\$ 0$}

\section{Reseña del Producto}

Primer Premio Internacional de Literatura David Mejía Velilla. El poemario ¿A dónde van los días transcurridos? inquiere con las preguntas siempre muy actuales desde la antigua tradición de la lírica. El autor demuestra la validez genuina de las indagaciones del hombre acerca del tiempo, el espacio, el sentido de la vida. Su lírica, de honda reflexión, invita al lector a concebir las dimensiones de la existencia.

\section{Información Adicional}

Sku: 9789581203864

Código topografico: 861.64

\section{Tabla de contenido}

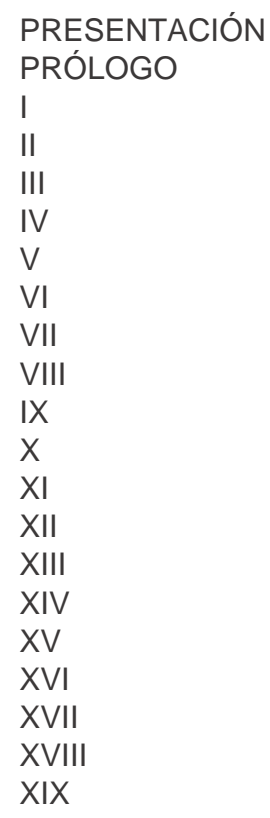


$X X V I$

$X X V I I$

XXVIII

XXIX

$X X X$

XXXI 